\title{
Assesment of factors influencing economical sustainability of women self-help groups
}

\author{
GAYATRI BISWAL*, SABITA MISHRA ${ }^{\mathbf{1}}$ AND PRAGATIKA MISHRA ${ }^{2}$ \\ Department of Home Science, R.D. Women's University, BHUBANESWAR (ODISHA) INDIA \\ ${ }^{1}$ DRWA (ICAR), BHUBANESWAR (ODISHA) INDIA \\ ${ }^{2}$ Utkal University, BHUBANESWAR (ODISHA) INDIA
}

\begin{abstract}
The study, "assessment the factors influencing economical sustainability of women self-help group" was conducted in three districts of Odisha namely, Cuttack, Puri and Khurda. About 240 women were selected randomly as respondents being members of SHG. Data were collected through personal interview method by using a pre-tested interview schedule and attempt was made to know the factors influencing economical sustainability of women self-help group. It was found that cohesiveness, co-operation, technical support, training, financial management, income generating programme, marketing are the major contributing factors for sustainability, whereas the least contributing features were found to be production and incentives.
\end{abstract}

KEY Words : Economical, Sustainability, Women, Self-help group

View Point Article : Biswal, Gayatri, Mishra, Sabita and Mishra, Pragatika (2017). Assesment of factors influencing economical sustainability of women self-help groups Internat. J. Home Sci. Extn. \& Comm. Manage., 4 (1): 48-52. DOI : 10.15740/HAS/IJHSECM/4.1/48-52.

Article History : Received : 13.11.2016; Revised : 05.12.2016; Accepted : 22.12.2016

\footnotetext{
* Author for correspondence
} 